UDC 338.001 .36

DOI: $10.15587 / 2312-8372.2018 .124687$

\section{Kyrylenko L.,} Shmygol' $\mathbf{N}$.

\title{
ASSESSMENT OF THE STATE OF MACHINE-BUILDING INDUSTRY IN UKRAINE
}

Проаналізовані показники діяльності машинобудівних підприємств України у 2010-2016 роках. Визначено, що машинобудування відіграє велику роль у змічненні економічного стану держави, активно впливаючи на формування показників сочіально-економічного розвитку України. Зроблено висновок про те, що всі перелічені проблеми значним чином викликані відсутністю реальних джерел фінансування, що спричиняє погіршення матеріально-технічної забезпеченості, та відповідно, низьку якість та високу собівартість продукції.

Ключові слова: машинобудівні підприємства, індекс промисловості, обсяги виробництва, соціально-економічний розвиток України.

\section{Introduction}

Industry is the basis of the national economy, the state of Ukraine and its economy depends on its sustainable development. In the structure of industry, one of the defining places belongs to machine-building. This industry provides the national economy with machine tools, vehicles, agricultural machines, excavators, generators for power plants, technological equipment for factories and plants, and thereby contributes to the development of all branches of the economy. Thus, by issuing the means of production for the fuel-energy, agro-industrial, construction, forestry complex, engineering, machine-building provides automation of production. Machine-building is one of the most important industries, since it affects the efficiency and productivity of many spheres of the country's economic activity. In the Ukrainian economy, machine-building enterprises faced the problems of increasing competitiveness in the international market and attracting additional financial and material resources. In Ukraine, at most enterprises, unlike other countries in the world, engineering is based on technologies left over from the times of the Soviet Union. This leads to a decrease in competitiveness and opportunities in world markets. Therefore, it is timely to conduct a study of the assessment of the state of the machine-building industry in Ukraine, to identify existing problems and their solutions.

\section{The object of research and its technological audit}

The object of research is the machine-building industry of Ukraine, which is one of the most important industries of Ukraine. One of the most problematic places is the reduction in the volume of production and sales of products, the decrease in sales markets due to the crisis situation in Ukraine.

With the purpose of assessing the state of the machine-building industry in Ukraine, an analytical study of indicators and indices of the production volume of the industry as a whole, and machine-building by types in particular. The data was taken from the site of the State Statistics Service of Ukraine and the official site of the Zaporizhzhia State Regional Administration.

\section{The aim and objectives of research}

The aim of research is evaluation of the performance indicators of the machine-building industry of Ukraine in recent years and building a causal relationship between the problems of machine-building enterprises in Ukraine.

To achieve this aim, it is necessary to perform the following tasks:

1. To calculate and evaluate the indicators of profitability of the operating activity of enterprises by types of machine-building.

2. To carry out an assessment of the performance indicators of machine-building in the Zaporizhzhia region.

3. To identify the factors, inhibiting the development of Ukrainian machine-building enterprises.

\section{Research of existing solutions of the problem}

Many scientists and practitioners are engaged in the research of the machine-building industry of Ukraine. The study [1] examines the export potential of enterprises in the machine-building industry of the Zaporizhzhia region, which indicates its current state, problems and prospects. In works [2, 3] the tendencies of the development of the machine-building industry in the economic development of Ukraine are considered and the problems encountered by the industry enterprises are highlighted.

In [4-8], it is proposed to apply an assessment of the financial state using the coefficient analysis in separate areas of analysis, in turn allows analyzing enterprises in spite of the scale of activity and determining the efficiency of the enterprise.

Alternative methods of evaluation are the use of diagnostic methods, first of all they began to be used in the practice of management consulting of enterprises and organizations, which was covered in the works of economists [9, 10], which describes the practice of organizing the management consulting process.

Thus, the results of the analysis make it possible to draw conclusions that there are a lot of methods for evaluating the activity of enterprises in the machine-building industry, but it is still necessary to evaluate the activity 
of this branch in Ukraine in more detail, in order to find ways to improve its condition.

\section{Methods of research}

To solve the tasks, the following methods are used: analysis and synthesis, evaluation, one-dimensional and twodimensional comparison, horizontal and vertical analysis.

\section{Research results}

Economic growth and development of Ukraine is impossible without a stable socio-political and economic condition of the state. The basis of economically financial stability, functioning and welfare of the country is a harmonious system of branches of the national economy. The structure of the Ukrainian economy has developed in such way that engineering is an integration industry, since it determines the level of the country's production potential, its defense capability, and is the basis for the development of other industries. The machine-building branch ensures the introduction of the achievements of science, new technologies, means of production in other spheres of the economy. Machine-building belongs to the most important industries of Ukraine, it affects the productivity and efficiency of other industries. It is necessary to ensure further stable development of machine-building, since the development of the entire industrial complex of the country depends on innovation, product quality and conformity of the state of the industry to the needs of the economy. From the activities of machine-building as a whole, the competitiveness of goods and services depends both on the domestic and foreign markets.

The machine-building complex of Ukraine is today considered as the largest branch with prospects of development and which provides technical equipment, complex mechanization and automation of production processes. The industry has a complex structure, according to the State Statistics Service of Ukraine, in 2015 there were 4,483 enterprises of various forms of ownership and destination [11]. Machine-building of Ukraine includes 38 branches of production and almost completely covers production cycles for the creation of the most complex equipment. This industry is represented by the production of machinery and equipment (including mechanical equipment, general purpose machinery and equipment, for agriculture and forestry, machines and household appliances). As well as electrical and electronic equipment, vehicles (cars, trailers, railway rolling stock, aircraft, ships, etc.) [12].

An important role of the machinebuilding industry for the country's economy is confirmed by the fact that in the normative document «The National Targeted Economic Program for the Development of Industry for the Period until 2017», the sub-sectors of machine-building are named as priority. Sub-branches of machine-building include aviation, rocket and space, shipbuilding, automotive, etc. This document defines the conceptual basis of industrial policy in the state [13].
Ukraine has all the conditions for development and functioning of engineering: a good geographical location, labor and raw materials.

When statistical analysis of data on the volume of production of engineering products (Fig. 1), there is a chaotic development of engineering, the annual production volume fluctuates within a small increase or decrease. Such data testify to the lack of a clear program for development of enterprises in this industry and the lack of rapid development. In the case of which it is very difficult to predict the future state of the industry, there are no trends in direction to growth or decline in financial results. There is a need to increase the efficiency of engineering enterprises and attempt to predict and manage the risks of activities.

Over the past few years there has been a decline in industrial production in Ukraine, which indicates deterioration in the financial condition of enterprises that make up its structure. To characterize this situation, the industrial production index is used, which indicates the dynamics of the volume of industrial production and is calculated as the ratio of the current value to the volume of production in the base year (in monetary terms). The reasons for this situation in the industry is the slow restoration of enterprises to the pre-crisis level, the loss of product markets, a decrease in demand for these products, a decrease in the solvency of buyers, resulting in a decrease in cash receipts from the sale of products. Negative influences on the level of development of industrial enterprises are also factors such as political instability in the state and the absence of government programs for crisis management and the development of industrial enterprises.

Also in order to determine the general trends in the development of machine-building, the activity of industrial and machine-building enterprises is analyzed. According to the State Statistics Service of Ukraine, let's consider the index of the volume of production of industry and engineering in the period from 2010 to 2016. The results in Fig. 2 show that after the decline in production in 2015 , the economic indicators began to rise.

A study of the current state of the Ukrainian industry shows that there are problems in the engineering industry that are being solved slowly enough.

With the help of Table 1 let's reflect the profitability of the operating activity of enterprises by types of machine-building.

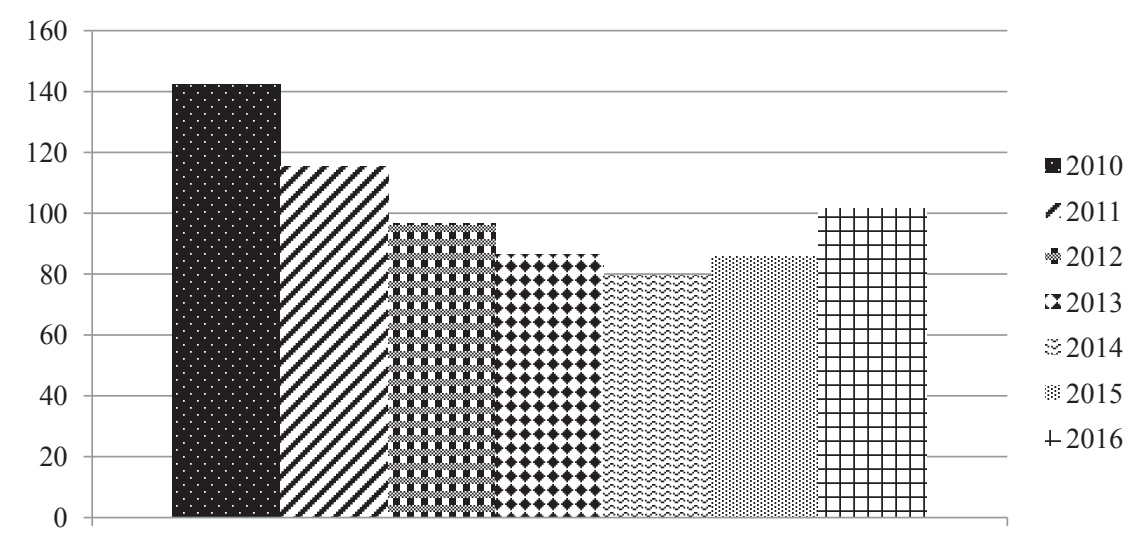

Machine-building

Fig. 1. Indices of volumes of production in machine-building for 2010-2016 (\% of previous year) [11] 


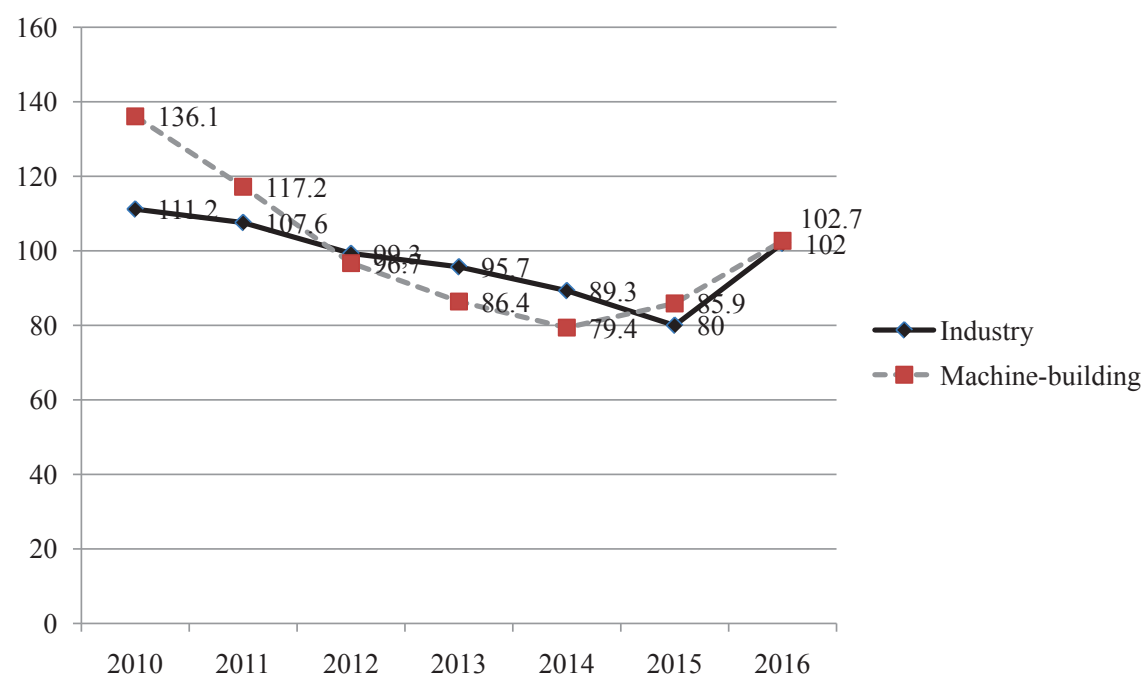

Fig. 2. Indices of production volumes of industry and machine-building in Ukraine in 2010-2016 (\% of previous year) [11]

Profitability of operating activity of enterprises by types of machine-building (million UAH)*

\begin{tabular}{|c|c|c|c|c|c|c|c|}
\hline \multicolumn{2}{|c|}{ Indicators } & $\begin{array}{l}\text { Industry of } \\
\text { Ukraine }\end{array}$ & $\begin{array}{l}\text { Machine- } \\
\text { building } \\
\text { (total) incl. }\end{array}$ & $\begin{array}{l}\text { Production of comput- } \\
\text { ers, electronic and } \\
\text { optical products }\end{array}$ & $\begin{array}{l}\text { Production of } \\
\text { electrical equip- } \\
\text { ment }\end{array}$ & $\begin{array}{l}\text { Production of machin- } \\
\text { ery and equipment not } \\
\text { elsewhere classified }\end{array}$ & $\begin{array}{l}\text { Production of motor vehicles, } \\
\text { trailers and semitrailers and } \\
\text { other vehicles }\end{array}$ \\
\hline \multirow{3}{*}{2010} & Result & 48602 & 10026 & 359 & 1359 & 2892 & 5415 \\
\hline & Costs & 1371650 & 143600 & 10083 & 21265 & 52545 & 59708 \\
\hline & Profitability, \% & 3.5 & 7 & 3.6 & 6.4 & 5.5 & 9.1 \\
\hline \multirow{3}{*}{2011} & Result & 81805 & 17789 & 1936 & 1028 & 3203 & 11621 \\
\hline & Costs & 1742909 & 191449 & 14005 & 24906 & 56754 & 95784 \\
\hline & Profitability, \% & 4.7 & 9.3 & 13.8 & 4.1 & 5.6 & 12.1 \\
\hline \multirow{3}{*}{2012} & Result & 52583 & 16598 & 584 & 2313 & 3017 & 10685 \\
\hline & Costs & 1568185 & 168409 & 10123 & 25007 & 48732 & 84547 \\
\hline & Profitability, \% & 3.4 & 9.9 & 5.8 & 9.3 & 6.2 & 12.6 \\
\hline \multirow{3}{*}{2013} & Result & 46273 & 9237 & 412 & 1998 & 2447 & 4379 \\
\hline & Costs & 1527701 & 139903 & 9921 & 24485 & 44910 & 60587 \\
\hline & Profitability, \% & 3 & 6.6 & 4.2 & 8.2 & 5.4 & 7.2 \\
\hline \multirow{3}{*}{2014} & Result & 37143 & -3978 & -1096 & -805 & -588 & -1489 \\
\hline & Costs & 1637281 & 139127 & 12936 & 26020 & 47383 & 52787 \\
\hline & Profitability, \% & 2.3 & -2.9 & -8.5 & -3.1 & -1.2 & -2.8 \\
\hline \multirow{3}{*}{2015} & Result & 47740 & 5511 & 155 & 469 & 2353 & 2533 \\
\hline & Costs & 1396820 & 106058 & 8440 & 18529 & 39094 & 39994 \\
\hline & Profitability, \% & 3.4 & 5.2 & 1.8 & 2.5 & 6.0 & 6.3 \\
\hline
\end{tabular}

Note: ${ }^{*}$ is built on the basis of data [11].

Fig. 3 reflects the change in the level of profitability of operating activity of enterprises of the machine-building industry in $2010-2015$.

According to the data shown in Fig. 3, it is observed that the profitability of the operating activity of enterprises by types of machine-building enterprises in 2014 markedly deteriorated and decreased to negative values of indicators. The indicator of the total profitability of industry for 2014 decreased from $3 \%$ to $2.3 \%$. But already in 2015 there is an improvement in performance, where the profitability index was $5.2 \%$. The engineering sector of Ukraine accounts for about $3.5 \%$ of GDP and $5.5 \%$ of the total employment in the country. Typically, machinebuilding is a relatively capital-intensive and technological sector of the economy demonstrates higher average labor productivity. However, the deficit of investment and technology in Ukraine indicates a huge shortage of productivity and leads to an aggravation of the crisis situation in the industry.

The deficit of capital and technology in Ukraine, caused by the action of two factors:

1) low labor costs are an incentive for an effective combination of production factors in the direction of more labor-intensive production until the costs of labor grow; 
2) poor access to credit and high interest rates reduce incentives to invest in fixed assets.

One of the reasons for the decrease in the profitability of the enterprises of the machine-building complex of Ukraine is the decrease in the volume of production. Significantly, the decrease in production volumes has reduced the supply of foreign raw materials, materials, energy resources, semi-finished products and components, and the entry of cheaper products into the market.

Table 2 shows the volume of sold industrial products (goods, services) in general for industrial activities and machine-building industry in 2010-2016.

According to the results of Table 2, let's observe that the volumes of sold products occupy almost a tenth of the total volume of industrial production in Ukraine over the last 6 years. At the same time, there is a tendency to reduce the production of machine-building enterprises, which starts to decline from 2012 from $10.3 \%$ to 2016, $6.1 \%$. This indicates an aggravation of the crisis in one of the leading sectors of Ukraine.

The management of the machinebuilding enterprise in the conditions of the crisis should be aimed at increasing the flow of financial resources and reducing current expenditures. Attention should be paid to the development of high-tech industries, which in turn will lead to a decrease in the material consumption of products, to an improvement in quality and to a new level of production, which will allow to occupy new niches in the world market. It is necessary not to forget about increasing the competitiveness of products on world markets, for this it is necessary to ensure, in turn, product quality, its reliability and durability.
Great importance for the overall indicators and the further development of Ukraine has engineering, and one of the largest regions - the commodity producers of the machine-building industry is the Zaporizhzhia region. This is the most numerous industry in the region. For the economy of the Zaporizhzhia region, the machine-building complex is system-forming and is represented by more than one hundred enterprises.

Zaporizhzhia region is the center of industry in the south of the country, it has considerable scientific, technical and industrial potential. The region is the center of Ukrainian aircraft engines, the production of transformers, cars.

Therefore, when studying and analyzing the state of machine-building, it is necessary to separately analyze the state of machine-building in this region. This will identify problems and determine the prospects for development of machine-building in Ukraine.

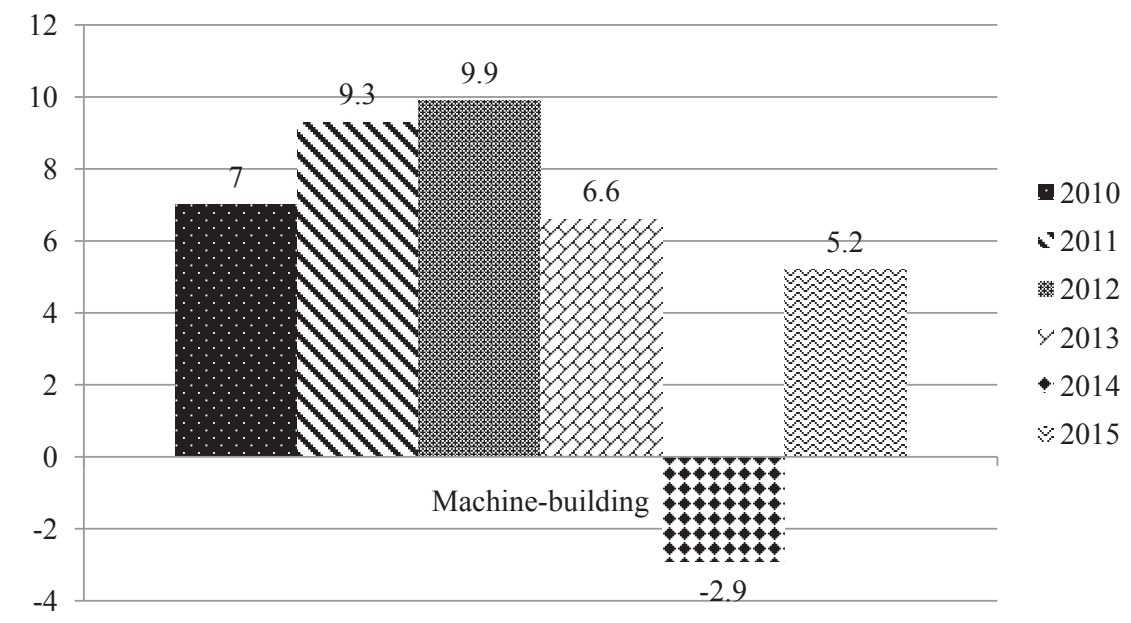

Fig. 3. Change in profitability of operating activity of enterprises of the machine-building industry in 2010-2015 (\%) [11]

Volumes of sold industrial products (goods, services) by types of production for 2010-2016*

\begin{tabular}{|c|c|c|c|c|c|c|c|}
\hline \multicolumn{2}{|r|}{ Indicators } & $\begin{array}{l}\text { Industry of } \\
\text { Ukraine }\end{array}$ & $\begin{array}{l}\text { Machine- } \\
\text { building } \\
\text { (total) incl. }\end{array}$ & $\begin{array}{l}\text { Production of com- } \\
\text { puters, electronic and } \\
\text { optical products }\end{array}$ & $\begin{array}{l}\text { Production of } \\
\text { electrical equip- }\end{array}$ & $\begin{array}{l}\text { Production of machin- } \\
\text { ery and equipment not }\end{array}$ & $\begin{array}{l}\text { Production of motor ve- } \\
\text { hicles, trailers and semitrail- }\end{array}$ \\
\hline \multirow{2}{*}{2010} & million UAH & 1043110.8 & 97056.9 & 6691.4 & 15755.2 & 30608.7 & 44001.6 \\
\hline & in $\%$ of the total & 100 & 9.3 & 0.7 & 1.5 & 2.9 & 4.2 \\
\hline \multirow{2}{*}{2011} & million UAH & 1305308.0 & 130847.9 & 11529.0 & 16715.6 & 37622.8 & 64980.5 \\
\hline & in $\%$ of the total & 100 & 10.1 & 0.9 & 1.3 & 2.9 & 5.0 \\
\hline \multirow{2}{*}{2012} & million UAH & 1367925.5 & 140539.3 & 7876.8 & 22141.3 & 37567.8 & 72953.4 \\
\hline & in $\%$ of the total & 100 & 10.3 & 0.6 & 1.6 & 2.8 & 5.3 \\
\hline \multirow{2}{*}{2013} & million UAH & 1322408.4 & 113926.6 & 7508.7 & 21832.4 & 34782.4 & 49803.1 \\
\hline & in $\%$ of the total & 100 & 8.6 & 0.6 & 1.6 & 2.6 & 3.8 \\
\hline \multirow{2}{*}{2014} & million UAH & 1428839.1 & 101924.7 & 8133.4 & 21005.7 & 33524.8 & 39260.8 \\
\hline & in $\%$ of the total & 100 & 7.1 & 0.6 & 1.5 & 2.3 & 2.7 \\
\hline \multirow{2}{*}{2015} & million UAH & 1776603.7 & 115261.7 & 8772.9 & 24038.5 & 41998.0 & 40452.3 \\
\hline & in $\%$ of the total & 100 & 6.5 & 0.5 & 1.3 & 2.4 & 2.3 \\
\hline \multirow{2}{*}{2016} & million. UAH & 2158030.0 & 131351.8 & 12366.1 & 26594.6 & 50105.3 & 42285.8 \\
\hline & in $\%$ of the tatal & 100 & 6.1 & 0.6 & 1.2 & 2.3 & 2.0 \\
\hline
\end{tabular}

Note: ${ }^{*}$ is built on the basis of data [11]. 
The industry of Zaporizhzhia region retains the third place among the regions of Ukraine in terms of sold industrial products ( $8.9 \%$ of all sold products in Ukraine). However, the situation remains extremely complex and unresolved, production volumes are declining, this trend has been observed since mid-2014. For lack of demand for manufactured products, shortage of working capital and loss of sales markets, the industrial capacities of enterprises were only partially loaded. But some enterprises were able to keep their positions, for example, «Motor Sich» could increase production volumes by introducing a program of helicopter construction and development of new sales markets.

To determine the trends in the development of machinebuilding in the Zaporizhzhia region, the activity of industrial and engineering enterprises is analyzed. Also, the data of the Main Department of Statistics of Ukraine in the Zaporizhzhia region, namely indices of the volume of production of industry and machine-building in the period from 2013 to 2016 are also considered. The results are shown in Fig. 4, show that by 2014 there was a decline in the output of products of the machine-building industry. However, from there was an increase in the volumes of production both in machine-building and in industry as a whole.

The factors that inhibit the development of Ukrainian machine-building enterprises are:

- high moral and physical levels of depreciation of fixed assets in industry, a significant lag in the state of fixed assets from the technological level of developed countries;

- growth of unprofitable enterprises;

- lack of own financial resources for the development of production;

- low level of introduction of innovative developments and innovations in the industry;

- a decrease in the volume of investments in the machine-building industry by Ukrainian and foreign investors [15].

For the further development of industry and machinebuilding in the Zaporizhzhia region, it is necessary to take measures to change the existing development strategy and introduce modern management models, accelerate innovation development, apply new technologies, develop export potential and external relations. Also, an important measure to improve the competitiveness of enterprises is the reconstruction of the majority of machine-building enterprises and the liquidation of the existing unprofitable.

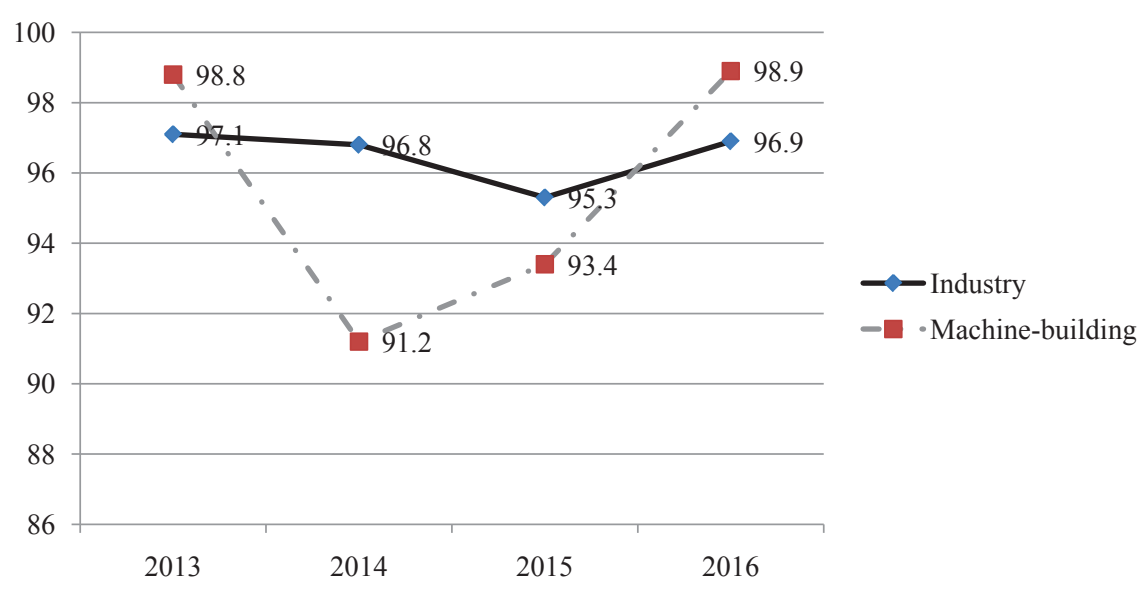

Fig. 4. Indices of the volume of production of industry and machine-building in the Zaporizhzhia region 2013-2016 (\% of previous year) [14]

\section{SWOT analysis of research results}

Strengths. An assessment of the state of the machinebuilding industry in the Zaporizhzhia region is conducted to identify weaknesses and bottlenecks in the industry, and to develop ways to improve.

Weaknesses. Weaknesses of the machine-building industry are:

- reduction of sales markets;

- finding cheaper products;

- reduction in demand.

Opportunities. Timely assessment of the state of the machine-building industry will allow to develop activities provided that all threats are taken into account and optimal solutions are found. For the successful development of the industry, it is necessary to maintain the competitiveness of products on the world and domestic market by improving quality and reliability.

Threats. A study of the current state of the Ukrainian industry shows that there are problems in the machinebuilding industry that are being solved slowly enough. At foreign enterprises, newer production technologies are used, which allow to reduce the cost of production and costs. In order for Ukrainian enterprises to improve their material base, it is necessary to invest a large amount of funds (investments) and develop new production standards.

\section{Conclusions}

1. The calculation and evaluation of profitability indicators of the operating activity of enterprises by types of machine-building are done. It is observed that the profitability of the operating activities of enterprises by types of machine-building enterprises in 2014 deteriorated noticeably and decreased to negative values of indicators. The indicator of the total profitability of industry for 2014 decreased from $3 \%$ to $2.3 \%$. But already in 2015 there was an improvement in performance, where the profitability index was $5.2 \%$.

2. The evaluation of the performance of machine-building in the Zaporizhzhia region is carried out. According to the calculated data, it can be said that the engineering industry of the Zaporizhzhia region is gradually gaining momentum in the production and sale of manufactured products. But since 2013, there has been a slight decline in the exports of machine-building products and of Ukraine in general and machine-building enterprises in the Zaporizhzhia region in particular. The prices of the $\mathrm{Za}$ porizhzhia region as one of the ways to improve the state of the machinebuilding industry is creation of joint ventures with foreign partners and increase investment attractiveness, because there are all conditions for efficient and profitable operation of industrial enterprises.

3. The factors constraining the development of Ukrainian machinebuilding enterprises are identified, among them the lack of high-tech industries, outdated management methods, low level of innovation and investment attractiveness. To overcome 
these negative factors and for the successful development of the industry, it is necessary to maintain the competitiveness of products on the global and domestic markets by improving the quality and reliability of the products.

\section{References}

1. Shmyhol N. M., Pavliuk T. S. Eksportnyi potentsial pidpryiemstv mashynobudivnoi haluzi zaporizkoho rehionu: suchasnyi stan, problemy, perspektyvy // Visnyk Zaporizkoho natsionalnoho universytetu. 2014. Vol. 3. P. 47-55.

2. Dovhun O. S. Dohovirni vidnosyny v konteksti rozvytku mashynobudivnykh pidpryiemstv: proceedings // Perspektyvy rozvytku ekonomika Ukrainy: teoriia, metodolohiia, praktyka. Lutsk: RVV «Vezha» VNU im. Lesi Ukrainky, 2009. P. 92-93.

3. Farynovych I. V. Tendentsii rozvytku mashynobudivnoi haluzi $\mathrm{v}$ ekonomichnomu rozvytku krainy // Naukovyi visnyk NLTU Ukrainy. 2009. Vol. 19.11. P. 83-88.

4. Bernstein L. A., Wild J. J. Financial Statement Analysis: Theory, Application and Interpretation. McGraw Hill, 2006. 738 p.

5. Brigham E. F., Ehrhardt M. C. Financial management: theory and practice. Thomson South-Western, 2008. 1074 p.

6. Fabozzi F. J. Financial Management and Analysis. John Wiley \& Sons, Inc., 2008. 1022 p.

7. Graham B. O., Meredith S. B. The Interpretation of Financial Statements. HarperBusiness Essentials, 2008. 135 p.

8. Finance Fundamentals of Corporate Finance. Vol. 1 / Whitehurst D. et al. 2003. 966 p.

9. Sabath R. E., Kubr M. Management Consulting, a Guide to the Profession // Journal of Marketing Research. 1977. Vol. 14 No. 3. P. 422. doi: $10.2307 / 3150794$

10. Yuksvyarav R. K., Khabakuk M. Ya., Leymann Ya. A. Upravlencheskoe konsul'tirovanie: teoriya i praktika. Moscow: Ekonomika. 1988. 240 p.

11. Ofitsiinyi sait Derzhavnoi sluzhby statystyky Ukrainy. URL http://ukrstat govua/

12. Bakuta A. V. Suchasnyi stan mashynobudivnoho kompleksu Ukrainy: problemy ta perspektyvy: proceedings // Problemy ekonomichnoho rozvytku v suchasnykh umovakh. Zaporizhzhia: Zaporizka derzhavna inzhenerna akademiia, 2012. P. 22-32. URL: http://www.zgia.zp.ua/gazeta/evzdia_2 022.pdf
13. Pro skhvalennia Kontseptsii Zahalnoderzhavnoi tsilovoi ekonomichnoi prohramy rozvytku promyslovosti na period do 2020 roku: rozporiadzhennia Kabinetu Ministriv Ukrainy 17 July 2013. No. 603-r // Baza danykh «Zakonodavstvo Ukrainy». URL: http://zakon0.rada.gov.ua/laws/show/603-2013-\%D1\%80

14. Ofitsinyi sait Holovne upravlinnia statystyky Ukrainy u Zaporizkii oblasti. URL: http://zp.ukrstat.gov.ua/

15. Korotkyi Yu. V. Mashynobudivna promyslovist Ukrainy: zdobutky ta perspektyvy // Naukovyi visnyk Mizhnarodnoho humanitarnoho universytetu. Seriia: «Ekonomika i menedzhment». 2015. Vol. 11. P. 117-120

\section{ОЦЕНКА СОСТОЯНИЯ МАШИНОСТРОИТЕЛЬНОЙ ОТРАСЛИ} УКРАИНЫ

Проанализированы показатели деятельности машиностроительных предприятий Украины в 2010-2016 годах. Определено, что машиностроение играет большую роль в укреплении экономического состояния государства, активно влияя на формирование показателей социально-экономического развития Украины. Сделан вывод о том, что все перечисленные проблемы в значительной степени вызваны отсутствием реальных источников финансирования, что вызывает ухудшение материально-технической обеспеченности, и соответственно, низкое качество и высокую себестоимость продукции.

Ключевые слова: машиностроительные предприятия, индекс промышленности, объемы производства, социально-экономическое развитие Украины.

Kyrylenko Liana, Postgraduate Student, Department of Accounting and Audit, Zaporizhzhia National University, Ukraine, e-mail: Sabrinalike1711@gmail.com, ORCID: http://orcid.org/0000-00030110-498X

Shmyhol' Nadiya, Doctor of Economic Sciences, Professor, Head of the Department of Accounting and Audit, Zaporizhzhia National University, Ukraine, e-mail: nadezdash@ua.fm, ORCID: http:// orcid.org/0000-0001-5932-6580

\section{Serbov M. DEVELOPMENT OF VALUE ESTIMATION OF COSTS OF FRESHWATER RESOURCES OF THE WATER BASIN BY THE OBJECTS OF NATURE USE}

Розглянуто методичні підходи до оцінки витрат на підготовку і використання прісноводних ресурсів водного басейну при різних видах господарської діяльності. Розглянута оптимальна стратегія безпечного і збалансованого розвитку економіко-екологічної системи водного басейну. Запропоновано схему вартісної оцінки витрат на невиробничі втрати природного ресурсу при його первинній та спеціальній підготовщі.

Ключові слова: прісноводні ресурси, оцінка втрат, витрати на підготовку природного ресурсу.

\section{Introduction}

Systemic and extremely negative anthropogenic processes occurring during the last decades, as well as errone- ous ideas about inexhaustibility and unlimited possibilities for self-purification of natural areas, resulted in significant disruptions in the development of economic and ecological systems. The world community unequivocally recognized 